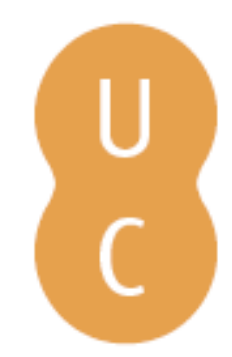

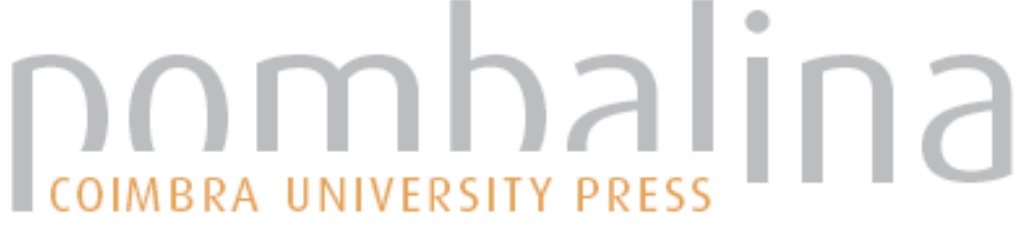

\section{Contemporary trends and issues in youth sports in Portugal}
Autor(es): $\quad$ Gonçalves, Carlos E; Silva, Manuel Coelho e
Publicado por: Coimbra University Press
URL persistente:
URI:http://hdl.handle.net/10316.2/32585
DOI:
DOl:http://dx.doi.org/10.14195/978-989-26-0412-1_1

Accessed : $\quad$ 26-Apr-2023 00:20:41

A navegação consulta e descarregamento dos títulos inseridos nas Bibliotecas Digitais UC Digitalis, UC Pombalina e UC Impactum, pressupõem a aceitação plena e sem reservas dos Termos e Condições de Uso destas Bibliotecas Digitais, disponíveis em https://digitalis.uc.pt/pt-pt/termos.

Conforme exposto nos referidos Termos e Condições de Uso, o descarregamento de títulos de acesso restrito requer uma licença válida de autorização devendo o utilizador aceder ao(s) documento(s) a partir de um endereço de IP da instituição detentora da supramencionada licença.

Ao utilizador é apenas permitido o descarregamento para uso pessoal, pelo que o emprego do(s) título(s) descarregado(s) para outro fim, designadamente comercial, carece de autorização do respetivo autor ou editor da obra.

Na medida em que todas as obras da UC Digitalis se encontram protegidas pelo Código do Direito de Autor e Direitos Conexos e demais legislação aplicável, toda a cópia, parcial ou total, deste documento, nos casos em que é legalmente admitida, deverá conter ou fazer-se acompanhar por este aviso.

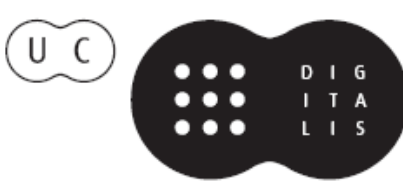


MANUEL COELHO E SILVA

ROBERT M. MALINA

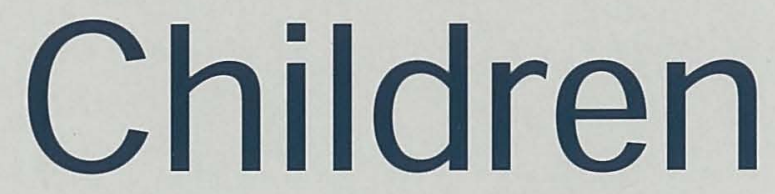

\section{and Youth}

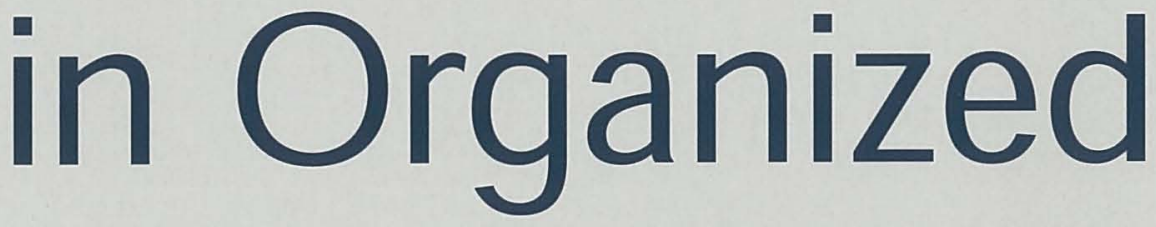

Sports 
(Página deixada propositadamente em branco) 
Manuel Coelho e Silva

Robert M. Malina

(Editors)

CHILDREN AND YOUTH IN ORGANIZED SPORTS

COIMBRA UNIVERSITY PRESS

2004 


$$
\begin{gathered}
\text { Editors } \\
\text { Manuel Coelho e Silva } \\
\text { and } \\
\text { Robert M. Malina } \\
\text { Publisher } \\
\text { Imprensa da Universidade de Coimbra } \\
\text { Coimbra University Press } \\
\text { Title } \\
\text { Children and Youth in Organized Sports }
\end{gathered}
$$

Date

March 2004

ISBN

972-8704-21-6

(Depósito legal n.: 208058/04)

Financial support

FCT Fundação para a Ciência e a 'Tecnologia MINISTÉRIO DA CIÊNCIA E DO ENSINO SUPERIOR Portugal

$$
\text { Apoio do Programa Operacional }
$$

Ciência, Tecnologia, Inovação do Quadro Comunitário de Apoio III

e

Câmara Municipal da Lousã

Faculdade de Ciências do Desporto e Educação Física

Universidade de Coimbra 


\section{CONTEMPORARY TRENDS AND ISSUES IN YOUTH SPORTS IN PORTUGAL}

Carlos E Gonçalves

Manuel Coelho e Silva

Youth Sport Institute. Faculty of Sport Science and Physical Education. University of Coimbra PORTUGAL

Over the past decades, several books and symposia have targeted the topic of the child in sport. One of the first was "Children and Sport: A Contemporary Anthology" (Magill et al., 1978), which went into two additional editions (Magill et al., 1982; Smoll et al., 1988). At the Olympic Scientific Congress in Eugene (Oregon) in 1984, one of the themes was "Competitive Sport for Children and Youth" (Weiss and Gould, 1986). Increasing interest in youth sports is also evident in subsequent volumes, including: "Advances in Pediatric Sport Sciences" (Boileau, 1984; Gould and Weiss, 1987); "Competitive Sports for Children and Youth" (Brown and Branta, 1988); "Young Athletes: Biological, Psychological and Educational Perspectives (Malina, 1988); "Sports and Children" (Chan and Micheli, 1998); "Children and Youth in Sport" (Smoll and Smith, 2002) and "Youth Sports: Perspectives for a New Century" (Malina and Clark, 2003). In Portugal, Sobral (1988a) introduced the topic of youth sports in a volume entitled "The Adolescent Athlete."

The purpose of the present paper is to highlight trends in youth sports in Portugal in the context of demographic and political changes over the past 25 to 30 years. In doing so, the paper draws on corresponding data from other countries to provide a comparative perspective.

\section{DEMOGRAPHIC TRENDS}

Sport is a central phenomenon in many societies. This trend has been labeled the "sportification of society" (De Knop et al., 1996a) and includes both participants and spectators. On an annual basis, about 23 million people visit sport parks to see professional games in Japan (Yamaguchi, 1996). Within the last decades German adolescents have doubled the time invested in informal and organized sport, in part, due to expanding education. (Brettschneider and Sack, 1996).

An important factor affecting sport participation is change in population composition. It is estimated that Europe will have 16.8 million fewer children and youth (0-19 years) in the year 2020 compared to 1990 (Eurostat, 1992). From the perspective of an individual country, for example, a decrease of 250,000 children and youth $<20$ years of age in Belgium has been projected 
between 2000 and 2050 (De Knop et al., 1996b). This is a large decrease which has major implications in a country of about 10 million inhabitants.

Portugal is a country that is similar population size to Belgium. The total population of Portugal increased 15.4\% between 1970 and 1991 (Barreto, 1997), but the distribution of the population has changed. The coastal area has attracted many investments and communications have improved to allow better access to Lisbon and Oporto. Municipalities located between these major urban areas show fairly reasonable demographic stability, due in part to the service and trade sectors. In contrast, inland areas have lost population. The trend began in the 1960s and 1970s when there was large scale emigration, primarily males, which was accompanied by a decline in birth rate. This had immediate implications for education. Education beyond compulsory attendance in some municipalities was no longer viable or was not been considered a priority issue by local authorities. Further, many schools have closed.

Under such conditions, those who remain in rural areas often do not have an opportunity to further their education. Individuals with interest in furthering their education are forced to move and often do not return. This situation compromises social developments, including sport among others. The promotion of sport participation is more difficult in rural communities since the youth population is not very large and is rather dispersed. Transportation within relatively vast areas is thus essential to create a club or even a team. Other developmental factors such as sport facilities and staff are also limited in rural areas. Although national data to this effect are not available, data for the District of Coimbra indicate a reduction in sport facilities and staff in rural areas (Coelho e Silva, 200 I).

\section{PATTERNS OF YOUTH SPORT PARTICIPATION}

\section{PARTICIPATION IN ORGANIZED SPORT}

Data for several countries indicate generally similar trends in youth sport participation. Note, however, that criteria for definition of sport participation are not universal and studies vary in sources of information and quality of data, e.g., official data versus specific surveys, self-report by youth and/or their parents, and so on.

It is estimated that 20 to 35 million children and youth $5-18$ years participated in non-school sports in the United States in the early 1990s (Ewing and Seefeldt, 1996). Although, these numbers probably represent an overestimation due to participation in more than one sport by many youth, they show the general interest of American youth in sport. The Campbell Survey of the Well-Being similarly demonstrated reasonably widespread 
participation in sport among Canadian youth. About $42 \%$ of males and $37 \%$ of females 10-14 years, and $44 \%$ of males and $28 \%$ of females $15-19$ years participated in competitive sports at least weekly (Stephens and Craig, 1990). About 47\% of Welsh youth $11-16$ years belonged to youth organizations (Sports Council for Wales, 1993), and as many as 54\% of 12 year old Finnish boys participated once a week in training sessions and competitions organized by sport clubs (Laakso et al., 1996).

Participation in organized sports peaks during adolescence and subsequently declines. Among Scottish yough, sport participation declines after a peak at 14-15 years of age, while attending entertainments such as discos, pubs and cinemas increases until 19-20 years (Hendry et al., 1993). The total number of Australian boys and girls that participates in sports peaks at I5-16 years of age (Blanksby et al, 1996). The percentage of adolescents engaged in organized sports increases from 38\% (boys) and 40\% (girls) at 12.5 years of age to $41 \%$ (boys) and 50\% (girls) at 16.5 years of age. Corresponding estimates for participation in recreational activities are $80 \%$ (boys), 54\% (girls) at 12.5 years of age, and $77 \%$ (boys), 57\% (girls) at 16.5 years of age in Australian youth. Finally, from ages 12.5 to 16.5 years, health and fitness activities increase from $8 \%$ to $15 \%$ in boys and $21 \%$ to $44 \%$ in girls.

According to Direcção-Geral dos Desportos (1988), about 130,000 Portuguese youth participated in competitive sport club activities in the mid1980s. This represented approximately $6 \%$ of the Portuguese population 6-18 years. In a more recent study (Marivoet, 200I), the highest rate of sport participation between 15 and 74 years of age occurred in Lisbon (27\%), followed by the North of Portugal (26\%), while the Midlands had the lowest rate (14\%). These estimates suggest that participation in sport activities is more common in urban settings.

\section{POPULARITY OF SPORTS}

Participation of Canadian youth 15-20 years by activity were: swimming (58\%), baseball (44\%) and ice hockey (40\%) for males, and swimming (69\%), skating (34\%) and baseball (30\%) for females (Stephens and Craig, 1990). In the United States, participation in school sports among youth $10-18$ years in order of popularity was as follows: football (16\%), track and field (16\%), basketball (16\%) and baseball (15\%) among males, and track and field (12\%), basketball (12\%), softball (11\%) and volleyball (10\%) among females (Seefeldt et al., 1992). Participation trends for high school sports in 1999-2000 in the United States are essentially the same (National Federation of State High School Associations, 200I).

The most popular sports among 5-15 year old New Zealand youth were: rugby (53\%), swimming (40\%), tennis (40\%), cycling (38\%), 
snooker/pool (39\%) for boys, and cycling (46\%), swimming (40\%), tennis (39\%), aerobics (39\%), netball (26\%) for girls (Russell et al., 1996). In an earlier survey of New Zealand youth 15 years of age, the picture of sport preferences was essentially the same with the exception of cricket which appeared as the third most popular sport among boys, after rugby and swimming (Reeder et al., 1991).

Popularity of sports among Flemish Belgian youth ranked swimming first among boys and girls, followed by soccer in boys and gymnastics in girls (De Knop et al., 1996b). In Finland, soccer and ice hockey were the most popular sports for boys, and gymnastics, track and field and volleyball were more popular among girls (Laakso et al., 1996). Telama (1988) detected Other popular activities among 14 year old Finns were jogging/running, cross-country skiing and biking (Telama, 1988).

Official estimates for popularity of competitive sport participation in Portugal in the mid-1980s, in order of popularity, were as follows: soccer, track and field, handball and basketball for boys, and track and field, gymnastics, handball and basketball for girls (Direcção-Geral dos Desportos, 1988). Data for youth 15-18 years actively participating in organized sport in the Portuguese Midlands in the late 1990s indicated that about $67 \%$ of males were engaged in team sports, whereas about $57 \%$ of females were engaged in individual sports (Coelho e Silva, 200I). The most popular sport for boys was soccer, followed by swimming and basketball; the three most popular sports for girls were swimming, soccer and basketball.

\section{YOUTH SPORT PROGRAMS IN PORTUGAL OVER THE PAST DECADES}

\section{YOUTH SPORTS PRIOR TO 1974}

Political and demographic changes in Portugal have influenced organizations, institutions and programs related to sport and also perceptions and concepts about the role of physical education and sport in society. This heritage can be briefly summarized as follows:

Government control of sport organization at all levels from national federations to regional and city organizations and clubs is the rule.

- Funds for facilities and activities come almost exclusively from public sources - central or local.

- The concept of sport as a non-priority activity with a nonrelevant contribution for material or social progress has resulted in a very small investment in sport for more than 40 years. 
- The low level of education of sport managers is due to the country's global situation and to the local character of the clubs (Teixeira de Sousa, 1988).

- $\quad$ The lack of scholarship and specific training of coaches is due to the limited number of faculties of Physical Education and Sport and of training programs for coaches in the sport federations.

- A reduced number of participants in sports and physical activities offered in schools and clubs is evident so that initiation of sport generally occurs rather late (adolescence), with the exception of soccer and exclusive swimming clubs with competitive programs (Gerardo and Gomes Ferreira, 2002).

As a result, the quality of performances and results were generally low for Portuguese athletes in major international competitions.

\section{ORGANIZATION AND PHILOSOPHY OF ORGANIZED YOUTH SPORT AFTER 1974}

\section{The Organization}

The new government retained control of sport in a department of the Ministry of Education that integrated Competitive Sport, School Sport and School Physical Education (Direcção Geral de Educação Física e Desportos, later Direç̧ão Geral dos Desportos - DGD). This situation changed in 1976, when Physical Education and School Sport became a new department comprising the basic and secondary school branches, beginning separate paths for club and school sport (rarely convergent, often in conflict) that has remained to the present. The dependence of sport on the Ministry of Education lasted till 1995, when the Ministry of Youth and Sport was created.

The Philosophy

The evolution of competitive youth sport in Portugal can be divided into three phases. Although is possible to observe a general pattern of changes during the last three decades (1974+), all federations did not move in the same directions, at the same time, and with the same speed. The major federations are those responsible for almost all youth sport activities in the country: soccer, basketball, handball, volleyball, hockey, track and field, swimming and judo.

1974-1985: Partnership between State and Sport Federations

After 1974 the public administration for sport declared its intention to build "a new sport for a new country" (Melo de Carvalho, 1975). The main 
concept was that sport is a factor of progress and socialization with significant impact on the quality of life for the people. Therefore, sport must be accessible to the total population with no limitations, including those who want to participate regardless of level of competence.

The Constitution of 1976 established that all citizens have the "right to sport" and so the State has the obligation to promote and support sport either for recreation or high-level performance. The main idea was to increase the number of participants in sport activities on a mass basis, especially among youth. During this period a program was created mainly to develop youth sports. To enforce this political choice, the government used several strategic options:

- $\quad$ The State must promote, support and "make" the activities in partnership with sport federations, clubs and organized citizens.

Funds for national federations were substantially increased, looking for rapid improvement of competitive sport quality.

- To consistently raise the quality of activity, it is vital to have an educated and trained staff - physical education teachers, coaches and club managers. Faculties of Physical Education were submitted to major changes, and Direcção Geral dos Desportos and federations started important programs of coaches education and training, setting the basis for a coaching career.

Both the State and federations looked to attract youth to sport stimulating a "boom" in sport participation among youth. The increased participation was specifically achieved through competitions for preadolescents and adolescents. As a result, the age of beginning for sport activities became much lower than before. The greatest increase in competitive youth sport participants - shown by the numbers of sport federations - was reached in the age group of $10-12$ years.

For sport federations, the mass provision of youth sport opportunities meant more funds from the government and a growing quality of high-level athletes. The concept was classic: from quantity appears quality. Until the mid1980s, federations multiplied the competitions for young people at local, district and national levels. At the same time, sport federations started to look with more attention to elite young athletes. With the new position of the country in the international domain, both State and federations saw international youth competitions as a way to prepare future Olympic champions and to gain prestige and advantages. Young national teams started to prepare and compete regularly in European championships and other international tournaments for specific age groups. 


\section{5-1995: Rise of elitism}

The partnership between the State and federations gradually started to move in favor of the federations. In 1985, the new government decided to abandon all organization of sport activities, but assumed a role related to funding, coordination (interface) and control. In this new position as the main actor in the sport system, federations began to define new areas of intervention in youth sport programs. From 1986 through the mid-1990s, all major federations started to look with a growing attention to their young elite athletes. Successes in international youth competitions, in turn, were viewed as a strategic option.

Poor results in international competitions in the previous years were seen as a consequence of several factors:

- Insufficient attention to elite young athletes,

- Lack of talent detection, selection and development programs,

- A small number of young athletes in elite programs,

- Lack of investment in training and international competitions for junior national teams, and

- $\quad$ Relatively low quality of coaches for youth.

Based on this analysis of the situation ("confirmed" by a poor presence of Portuguese athletes in the Seoul Olympic Games in 1988 and by successes of the national youth soccer teams in World Championships in the early 1990s), major sport federations, specifically soccer, basketball, handball, volleyball, athletics and swimming, took several strategic measures to strenghten their position internally and to obtain better results in international youth competitions and, later, in senior championships. Not all of the federations followed the same solutions, but there was a common view of the problems that led to some general options:

- Reinforce the so-called department of Recruiting and Promotion, with the task of increasing the number of young athletes and at the same time, to detect and select those with better aptitudes to that specific sport;

- $\quad$ Reinforce national team programs, which was seen as a tool for development towards quality and a way to achieve international success;

- Create a support program for national teams, based in district organizations, in order to increase the number of elite young 
athletes who follow a common training plan (some federations called this "the route to high performance"); and

Reinforce coach education and training programs in order to support the elite projects.

The suggested solutions to enforce these options were basically three:

Increase both the number of days spent by the national teams in training camps (national junior soccer teams start to spend more than 100 days/year in training camps), and participation in international competitions;

- Create a competition for district teams for boys and girls 12-16 years of age, where the elite young athletes would practice and compete under the guidance and observation of national coaches; and

Structure coach education and training program based on "levels" oriented toward the preparation of a high performance coach.

The "elite oriented programs" demanded a huge financial effort, forcing most of the major federations to compete for more money from the government and from sponsors. While the public funds were still dependent on the number of athletes enrolled, all federations retained programs and competitions for young children and adolescents, and encouraged the clubs to do the same. However, the contradiction between "mass" programs for children, mainly through "sport schools" and "mini" sports, and an orientation towards elitism was not solved by the sport federations until the present.

\section{5-2002: "Super elitism"}

The "super elite" model was regarded as a successful since soccer and handball had good results in European and world youth championships, at least until 1995/1996. However, it became obvious for many coaches and federation officials that this was not sufficient. The basic argument was that in order to meet the demands of international performance, practices and competitions only in clubs were insufficient to prepare youth for high level sport (e.g., Portuguese Basketball Association). In order to face progress of other countries, the best young athletes needed to remain in training camp and under national coaches throughout the year. With government support through the High Performance Center, some federations created their own centers, where young athletes 13 - I 8 years lived and practiced together. These youngsters (boys and girls) spent from $<300$ hours/year of training in clubs to 700 hours/year in performance centers. 
It was generally believed by both the government and federations that traditional clubs were in crisis (money and volunteers) and could not face the demands of high performance training programs, and that youth were also in crisis due to too much amusement, sedentarism and hedonism. Because most youngsters come to sport primarily for fun or enjoyment, the quality of athletes and competitions decreased and federations, through national teams, had to take special care of talented individuals.

At the same time, competitions within Portugal were seen more as an obstacle (due to the relatively low quality) than as a way to develop talented young athletes. Therefore, elite young athletes were viewed as needing to compete more frequently abroad and/or to participate in domestic competitions with older athletes (e.g., a 16 year old competing with an 18 year old).

In the same way, professional soccer clubs started to create their own training centers, believing that high performance and competition in a global market demanded a solid and professionally oriented preparation from very young ages (in some cases as early as 10 years). The club version of the Performance Centers is limited to soccer at present because the major clubs have adequate funds.

\section{A critical overview}

The dominant concepts regarding youth sports in Portugal are similar to those of other European countries. Sport federations do their job, searching to reach success in international competitions and to increase the popularity of their respective sports among youth. This competition for high performance results and for the "market share" - and also for more funds - is a fundamental task assumed by federation officials. However, the case of Portugal also has some local charateristics:

Due to weakness of activities, poverty of investments and lack of qualified personnel, the reception and implementation of international trends was late and inefficient in the local conditions in most instances;

- Due to the absence of good school sport programs, clubs and federations were responsible for almost all sports available for youth;

- Due to the lack of collobaration among faculties of Sport and Physical Education, the intervention of professors and sport scientists in the design and control of research into youth sports was not systematically established until the 1990s; 
- General acceptance (by almost all coaches and sports officials) that quantity insures quality of athletes;

- When it became evident that something was wrong with youth sport, federations designed programs to emphasize the training process with young elite athletes;

- "Super elitism" (high performance centers) was not anticipated by talent detection programs supervised by sport scientists;

- The need to increase the number of participants in competitions, determined by quantity based criteria for public funding and by competition for "market share", moved federations to start recruiting athletes at younger ages, with new teams, new competitions, more coaches, more referees, more training facilities, more travel, and so on; and

- The convergence of the increasing number of athletes and "super elitism" placed considerable pressure on the budgets of federations, consuming a large part of financial and human resources.

The situation obviously varies among federations. Some are paying attention to changes and listening to sport scientists in order to adapt to the needs of youth and to design new programs and new activities.

\section{SCHOOL SPORT PROGRAMS}

The organization of school sport since 1974 shows several inconsistencies, lack of clear policies, and conflict between schools and clubs. In 1974, the sport system - including school sport - was integrated in a department, Direç̧ão Geral dos Desportos (DGD), which was dependent on the Ministry of Education. In 1977, school sport was transfered to so-called "educational departments" in the Ministry of Education. The motives for this change were clearly expressed in Law 553/77: "School sport is an extra curriculum activity and makes sense only as a logical sequence of the curriculum activity (physical education classes); the intervention in school of non scholar organizations must be avoided."

In 1986, school sport returned to the competitive sport system, integrating again the DGD. However, Law 46/86 recognized the specificity of school sport and in 1989 a department of school sport, Gabinete Coordenador do Desporto Escolar (GCDE), was created. It integrated again the educational departments of the Ministry of Education, but was also dependent on the DGD. This solution was based in "the essential unity between physical education and school sport." In addition, "schools have their 
own specificity", despite the "cooperation that can be established with other organizations."

Sport Law I/90 and the Physical Education and School Sport Law 95/9 | stated that school sport is Sport and has its place in the sport system but, at the same time is "an activity made in school". Therefore, school sport is defined as a "subsystem totally integrated in the educational system" and also as an "independent part of the sport system where can be set up relations with clubs and federations", giving however the priority to education.

Subsequently, Laws 143/93 and I 15/95 established that the new Sport Institute (INDESP) must support the "competitive activities of school sport" and "coordinate the school sport activities and the correspondent facilities." According to Law 143/93, INDESP was integrated in the Ministry of Education. However, in 1995 Law 269 transfered the Institute to direct dependence on the prime minister, and in 1996 Law 164 withdrew all missions regarding school sport from INDESP.

Until now, the coordination of school sport remains in the Ministry of Education. All of the changes over almost 30 years were the visible face of the struggle led by physical education teachers to retain the power of decision regarding school sport. For most teachers, school sport is an educational activity that must be regulated by the schools and almost exclusively by physical education teachers with no interference from the outside. In the view of many, school sport had to be kept from the interference of the federations which were viewed as elitist.

School sport has an independent competition system. Boys and girls who participate in federation championships are not eligible for school competitions. However, schools can participate in federation competitions and federation athletes are eligible for international school championships!

School sport activities cover the basic and secondary schools, from $5^{\text {th }}$ to $12^{\text {th }}$ grades, under the supervision of a physical education teacher or other discipline teacher with a sport curriculum. The time spent in practices and competitions (4 hours/week) is included in the teacher's schedule, reducing the number of physical educaton classes. The activities are done during school free time and participation is voluntary.

For this reason, school sport is often viewed from the outside as an "island" in the sport system and is often criticized by coaches and federation officials as irrelevant to their goals. Current criticisms, especially on the occasion of some international defeat, are that sport in school does not exist, has poor quality, and does not provide national sport with a large number of young talented athletes. 
The actual situation of school sport is one of isolation and discredit in public opinion: no internal activity in school, few participants and competitions, poor quality of athletes and competitions, bureaucracy and exhibition activities. The criticisms previously addressed to federation sport are now applied to school sport. According to Pires (1996), the main problem of school sport is the lack of an objective.

\section{RESEARCH ISSUES IN YOUTH SPORTS}

Table 3 presents a selection of titles of papers, theses and/or books dealing with different aspects of youth sports in Portugal over the past 20 years. Early research on Sport Science and Physical Education was limited to an educational approach, whereas in the field of sport, studies were mainly focused on performance determinants in a perspective of optimization. Sobral (1984) stressed the importance of studying structural and functional conditions related to the attainment and maintenance of a high level of performance. Subsequently, knowledge developed within several disciplines with interests in sport and physical activity has reformulated prevailing paradigms and guidelines: from athletic related fitness (Araújo, 1985) to psychosocial determinants of sport adherence and drop-out (Serpa, 1990), and from an initial emphasis on biology (Sobral, 1984) to a psychosocial emphasis (Gonçalves, 1990; Marivoet, 200 I).

Problems such as elitism, satisfaction of children and youth engaged in sports, motives for coaching activity, coach attrition, retrospective analysis of former youth athletes submitted to intensive training, and others are lacking in the Portuguese literature. Many of these unanswered questions require an interdisciplinary approach.

Table 3. Selection of sport science.

\begin{tabular}{llll}
\hline Author & Year & Subject & Title \\
\hline Sobral & 1984 & Morphology and sport & PhD thesis \\
Araújo & 1985 & Sport talent selection & Article \\
Sobral & 1988 & The adolescent athlete & Book \\
Lima & 1989 & Premature exclusion of youth athletes & Article \\
Sobral and Marques & 1990 & Excellency in youth school population & Book \\
Serpa & 1990 & Participation Motivation & Chapter \\
Gonçalves & 1990 & Fair-play & Article \\
Marques & $199 \mid$ & Basis for talent identification in Portugal & Article \\
Vasconcelos Raposo & 1993 & Psychological, social and cultural factors that influence & PhD thesis \\
& & goal achievement among Portuguese top atletes & \\
Maia & 1993 & Anthropobiological approach on sport selection & PhD thesis \\
Sobral & 1994 & Youth sports: readiness and talent & Book \\
Adelino et al. & 1999 & Youth training & Book \\
Fonseca and Maia & 2000 & Motivation of youth athletes & Book \\
Marivoet & 2001 & Sport habits in the Portuguese population & Book \\
\hline
\end{tabular}


Participation in sports is one of the most important dimensions of socialization in contemporary society. Participation in sports is not compatible with unidimensional perspectives that sacrifice the complexity of its nature to the accuracy of experimental methodologies. Sobral (1996) suggested that such broad concepts as sport participation, physical fitness, and lifestyle are first and foremost biocultural topics that are not compatible with the relatively narrow perspectives that persists in some academic communities. Therefore, after a period dominated by non-contextual viewpoints, an era of comprehensive, holistic and temporal analyses is needed.

\section{OVERVIEW AND RECOMMENDATIONS}

Although competitive sports are popular, the demands of long-term preparation are being identified as a main factor in drop-out.

- New organizations (mostly coach free) in youth sports oriented by commercial proposals ( $3 \times 3$ basketball, beach volley) have emerged in the past few years. As a result, competitive sports are starting to face a decrease in youth participants. Concurrently, children and youth are being attracted to more and more non-sport leisure activities, such as skate boarding, surfing, electronic sport games, among others.

- $\quad$ Programs oriented towards elitism need to assume alternative strategies to the view that top athletes develop from mass sport participation. By taking this challenge into account, many federations are promoting highperformance centers for talented youth athletes. Unfortunately, these programs are relatively spontaneous and do not ordinarily include sport scientists.

- Youth sport organization would be negatively affected by the promotion of a narrow number of candidates for participation in highperformance levels. The success of talent detection, selection and development depends on the quality of interventions acting long before sport specialization.

\section{LITERATURE}

Adelino J, Vieira J, Coelho O (1999). Treino de jovens - o que todos precisam de saber.

Centro de Estudos e Formação Desportiva. Secretaria de Estado do Desporto.

Araújo J (1995): A Selecção em Basquetebol. Seminário Internacional "A Equação da Selecção". Faculdade de Ciências do Desporto e Educação Física - Universidade do Porto.

Barreto A (1997). A situação social em Portugal. Instituto de Ciências Sociais Universidade de Lisboa.

Blanksby B, Anderson M, Douglas G (1996). Recreational patterns, body composition and socio-economic status of western Australian secondary school students. Annals of Human Biology. 23 (2): $101-1$ I2. 
Boileau R (1984). Advances in pediatric sport sciences. Vol. I: biological issue. Champaign, Illinois. Human Kinetics.

Brettschneider WD, Sack HG (1996). Youth sport in Europe - Germany. In P De Knop, L-M Engstrom, B Skirstad, MR Weiss (Eds). Worldwide trends in youth sports. Champaign, Illinois. Human Kinetics. Pp: I39-151.

Brown EW, Branta CF (1988) Competitive Sports for Children and Youth: An Overview of Research Issues. Champaign, IL: Human Kinetics.

Chan KM, Micheli LJ (1998) Sports and Children. Hong Kong: Williams and Wilkins Asia Pacific Ltd.

Coelho e Silva MJ (200I). Morfologia e Estilo de Vida na Adolescência - Um Estudo em Adolescentes Escolares do Distrito de Coimbra. Dissertação de Doutoramento. Faculdade de Ciências do Desporto e Educação Física. Universidade de Coimbra.

Constantino JM (1992) Desporto português - as soluções adiadas. Lisboa. Livros Horizonte.

De Knop P, Skirstad B, Engstron L-M, Theeboom M, Wittock H (1996a). Sport in a changing society. In P De Knop, L-M Engstrom, B Skirstad, MR Weiss (Eds). Worldwide trends in youth sports. Champaign, !llinois. Human Kinetics. Pp: 8- 14.

De Knop P, Vanreusel B, Theebom M, Wittock H (1996b). Youth sport in Europe Belgium. In P De Knop, L-M Engstrom, B Skirstad, MR Weiss (Eds). Worldwide trends in youth sports. Champaign, Illinois. Human Kinetics. Pp: 88- 100.

Direcção-Geral dos Desportos (1988). Atlas desportivo nacional. Lisboa. Direcção Geral dos Desportos.

Eurostat (1992). Demographic statistics 1991. Luxembourg. Eurostat.

Ewing ME, Seefeldt $V$ (1996). Patterns of participation and attrition in American agency-sponsored youth sports. In FL Smoll and RE Smith (Eds). Children in sport: a biopsychosocial perspective. Indianapolis. Brown \& Benchmark. Pp: 31-45.

Federação Portuguesa de Basquetebol (1986). Plano estratégico 86/88. Lisboa. Fedração Portuguesa de Basquetebol.

Fonseca AM, Maia J (2000). A Motivação dos Jovens para a Prática Desportiva Federada. Centro de Estudos e Formação Desportiva. Ministério da Juventude e Desporto.

Gerardo F, Gomes Ferreira A (2002). As origens do movimento associativo na cidade de Coimbra. In F Sobral, M Coelho e Silva (Eds). Demografia e Jovens no Desporto. Lisboa. Centro de Estudos e Formação Desportiva.

Gonçalves C (1990). Fair play and youth sport participants. In R Telama, L Laakso, M Piéron, I Ruoppila, V Vihko (Eds). Physical Education and Life-Long Physical Activity. Jyvaskyla, Finland. AIESEP. Pp: | 37-I43.

28 Gonçalves C (1996). Youth sport in Europe: Portugal. In P De Knop, LM Engstrom, B Skirstad, MR Weiss (Eds). Worldwide trends in youth sport. Human Kinetics Publishers, Inc. Champaign, Illinois. Pp: 193-203.

Gould D, Weiss MR (1987). Advances in pediatric sport sciences. Vol. 2: behavioral issues. Champaign, Illinois. Human Kinetics.

Hendry L, Shucksmith J, Love J, Glendinning A (1993). Young people's leisure and lifestyles. London. Routledge.

Laakso L, Telama R, Yang X (1996). Youth sport in Europe - Finland. In P De Knop, LM Engstrom, B Skirstad, MR Weiss (Eds). Worldwide trends in youth sports. Champaign, Illinois. Human Kinetics. Pp: 126-I38. 
Lima T (1989). A eliminação desportiva precoce. Treino Desportivo. I/ Série ( 15$)$ : 25-32. Maia J (1993): Abordagem Antropobiológica da Selecção em Desporto - Estudo Multivariado de Indicadores Bio-Sociais da Selecção em Andebolistas dos Dois Sexos dos 13 aos 16 Anos de Idade. PhD dissertation. Faculdade de Ciências do Desporto e Educação Física - Universidade do Porto.

Magill RA, MJ Ash, FL Smoll (1972). Children in sport: A contemporary anthology.Champaign, IL: Human Kinetics.

Magill RA, MJ Ash, FL Smoll (1982). Children in sport, $2^{\text {nd }}$ edition. Champaign, IL: Human Kinetics.

Malina RM (1988). Young athletes: biological, psychological and educational perspectives. Champaign, Illinois. Human Kinetics. Pp: 121 - 140.

Malina RM, Clark MA (2003). Youth sports - perspectives for a new century. Monterey, CA. Coaches Choice.

Marivoet S (200I). Hábitos Desportivos da População Portuguesa. Centro de Estudos e Formação Desportiva. Ministério da Juventude e Desporto.

Marques A (|99|): Bases Para a Estruturação de Um Modelo de Detecção e Selecção de Talentos Desportivos em Portugal. In J Bento, A Marques (Eds). As Ciências do Desporto e a Prática Desportiva. $1^{\circ}$ Volume. Desporto na Escola. Desporto de Reeducação e Reabilitação. Faculdade de Ciências do Desporto e Educação Física Universidade do Porto.

Melo de Carvalho A (1987). Desporto Escolar - Inovação pedagógica e nova escola. Lisboa. Editorial Caminho.

National Federation of State High School Associations (200I). The case of high school activities, http://www.nfsh.org/case.htm.

Pires G (1996). Desporto escolar - desenvolvimento e gestão de projectos. Departamento de Ciências do Desporto - Faculdade de Motricidade Humana - Universidade Técnica de Lisboa.

Reeder Al, Stanton WR, Chalmers DJ (199|). Adolescents' sporting and leisure time physical activities during their $15^{\text {th }}$ year. Canadian Journal of Sport Sciences. Vol. 16 (4):308-315.

Russell DG, Allen JB, Wilson NC (1996). Youth sport in Oceania: New Zealand. In P De Knop, LM Engstrom, B Skirstad, MR Weiss (Eds). Worldwide trends in youth sport. Champaign, Illinois. Human Kinetics. Pp: 260-274.

Seefeldt V, Ewing ME, Walk S (1992). Ovenview of youth sport programs in the United States. Washington DC. Carnegie Council on Adolescent Development.

Serpa S (1990). Motivação para a prática desportiva. In F Sobral, A Marques (Coordenadores). FACDEX: Desenvolvimento somato-motor e factores de excelência desportiva na população escolar portuguesa. Ministério da Educação - Desporto Escolar. Pp: I0I-106.

Smoll FL, Magill RA, Ash MJ (1988). Children in Sport, $3^{\text {rd }}$ edtition. Champaign, IL. Human Kinetics.

Smoll FL, Smith RE (2002) Children and Youth in Sport: A Biopsychosocial Perspective. Dubuque, IA: Kendall Hunt.

Sobral F, Marques A (1990). FACDEX: Desenvolvimento somato-motor e factores de excelência desportiva na população escolar portuguesa. Ministério da Educação Desporto Escolar. 
Sobral F (1984). Morfologia e Prestação Desportiva na Adolescência. Instituto Superior de Educação Física - Universidade Técnica de Lisboa.

Sobral F (1988). O adolescente atleta. Lisboa. Livros Horizonte.

Sobral F (1994). Desporto Infanto-Juvenil: Prontidão e Talento. Livros Horizonte. Lisboa.

Sobral F (1996). Lifestyle and habitual physical activity: a biocultural perspective. In $F$ Sobral, A Faro (Eds). Vida activa - da escola à comunidade. Actas do $7^{\circ}$ Congresso Europeu ICHPERD-SD. Universidade de Coimbra : I I5- 122.

Teixeira de Sousa JO (1988). Contributo para o estudo do associativismo desportivo em Portugal. Instituto Superior de Educação Física - Universidade Técnica de Lisboa.

Sports Council for Wales (1993). Children's sport participation 1991-1992. Cardiff, Wales: Sports Council for Wales.

Stephens T, Craig CL (1990). The well-being of Canadians: highlights of the 1988 Campell's Survey. Ottawa. Ontario. Canadian Fitness and Lifestyle Research Institute.

Telama R (1988). Sports in and out of School. RM Malina (Ed). Young athletes: biological, psychological, and educational perspectives. Champaign, Illinois. Human Kinetics. Pp: 205-221.

Vasconcelos Raposo J (1993). Os factores psico-sócio-culturais que influenciam e determinam a busca da excelência pelos atletas da elite desportiva portuguesa. Tese de Doutoramento. Universidade de Trás-os-Montes e Alto Douro. Vila Real

Weiss MR, Gould D, Eds (1986). Competitive sport for children and youths. Champaign, Illinois. Human Kinetics.

Yamaguchi Y (1996). Youth Sport in Asia - Japan. In P De Knop, LM Engstrom, B Skirstad, MR Weiss (Eds). Worldwide trends in youth sports. Champaign, Illinois. Human Kinetics. Pp: 67-75. 
Série

Investigacão

Coimbra

Imprensa da Universidade

2004 